\title{
Currículo, rituais e negociações de gênero
}

\section{School curriculum, rituals and gender negotiations}

\author{
Iara Maria de Araújo ${ }^{1}$, Tatiane Bantim da Cruz ${ }^{2}$
}

\begin{abstract}
RESUMO
A escola exerce um papel fundamental na construção das identidades de gênero. É no âmbito da prática curricular, nos rituais cotidianos da escola que as feminilidades e masculinidades vão sendo construídas, negociadas ou até mesmo transgredidas. A intenção do estudo é analisar as concepções de feminilidades e masculinidades produzidas e reproduzidas no contexto escolar, e as implicações dessas concepções nas relações de gênero, atentando para a forma como a escola lida com as transgressões de gênero. Foi realizada uma pesquisa de cunho qualitativo em uma escola pública de ensino fundamental, momento que foram realizadas observações do cotidiano escolar em distintos espaços de socialização. Pode-se perceber que a escola participa ativamente do processo de construção das identidades de gênero dos indivíduos na medida em que delimita espaços e fronteiras, separa meninas dos meninos, lança expectativas diferenciadas, naturaliza noções de feminilidades e masculinidades, reproduz preconceitos, desconsidera as desigualdades, entre outras situações.

No mesmo idioma do artigo, com no mínimo cinco e no máximo 12 linhas. Deve constar em fonte Times New Roman, corpo 10, justificado, espaçamento 1,15 entre as linhas. O resumo é obrigatório e considerado um dos principais componentes do manuscrito. Lembre-se que um bom resumo deve descrever quais são os objetivos do trabalho e os pontos metodológicos de forma sucinta. Mostrar os principais resultados que respondem ao propósito do estudo.
\end{abstract}

Palavras-chave: Gênero; Educação; Currículo; Rituais.

\begin{abstract}
Schools perform a fundamental role in gender identity development. It is within the scope of the curriculum practice, in the daily school rituals that femininities and masculinities are being built, negotiated, and even transgressed. The purpose of this study is to analyze the conceptions of femininities and masculinities produced and reproduced at the school environment, and the implications of such conceptions in the gender relations, observing the way in which schools deal with gender transgression. A qualitative research was carried out at a public elementary school, where observations were made about its routine at different socializations spaces. Through the research, it was observed that the school actively participates in the individuals gender identity development process, as far as it delimits spaces and borders, splits girls from boys, introduces differentiated expectations, naturalizes femininity and masculinity notions, reproduces prejudices, ignores inequalities, among other situations.
\end{abstract}

Keywords: Key words1; Gender; Key words2, Education; Key words3 School curriculum; Key words4; Rituals.

\footnotetext{
${ }^{1}$ Universidade Regional do Cariri. E-mail: iara.mar@terra.com.br

${ }^{2}$ Universidade Regional do Cariri. E-mail: tatianebantim@ @otmail.com
} 


\section{INTRODUÇÃO}

A escola representa importante espaço de socialização e aprendizagem, principalmente para crianças e jovens, que deixam de pertencer somente aos espaços restritos da família e passam a se relacionar com pessoas provenientes de outros contextos, costumes, valores e outras experiências de vida. É nesse ambiente, não exclusivamente, que os indivíduos têm acesso ao conhecimento científico, sistematizado e, da mesma forma, a saberes de vida e de mundo, relativo às noções, culturalmente construídas, sobre certo e errado, bem e mal, legal e ilegal, ético e antiético, entre outras que influenciam no desenvolvimento do ser. É também nesse espaço que meninas e meninos entram em contato com o outro, aquele que é diferente deles.

Para Paechter (2009), as instituições responsáveis por esse processo de socialização são chamadas de comunidades de prática. Essas comunidades são responsáveis pela inserção social dos indivíduos e, a partir das relações estabelecidas com os outros, vão se constituindo como membros sociais e construindo suas identidades. É no contato com o outro que as noções de feminilidades e masculinidades vão sendo incorporadas e as identidades vão sendo construídas e transformadas.

A escola exerce um papel fundamental na construção das identidades de gênero. Toda a organização da escola, os materiais didáticos, os conteúdos, as separações, a decoração, representações, discursos e até mesmo os silêncios influenciam na construção das identidades. Ou seja, é no âmbito da prática curricular, nos rituais cotidianos da escola que as feminilidades e masculinidades vão sendo construídas, negociadas ou até mesmo transgredidas.

Quando esse fazer escolar se encontra prescrito, é possível afirmar que se trata da dimensão formal do currículo, aquilo que se encontra escrito nos diversos documentos que regem o sistema educacional como um todo e que são orientados e determinados pela legislação educacional brasileira, como a Constituição Federal de 1988, a Lei 9394/96 (Lei de Diretrizes e Bases da Educação Nacional) e a Base Nacional Comum Curricular (BNCC). Essas orientações e determinações são expressas no Regimento Escolar, no Projeto Político Pedagógico e, mais especificamente, nos planos de aula de cada professora e professor, trazendo, é claro, as especificidades de cada contexto educacional, sala de aula e disciplina.

Porém, nem tudo que acontece na escola está prescrito nos documentos educacionais, considerando a existência de outra dimensão do currículo, a oculta. Conforme Silva afirma: "O currículo oculto é constituído por todos aqueles aspectos do ambiente escolar que, sem fazer parte do currículo oficial, explícito, contribuem, de forma implícita, para aprendizagens sociais relevantes" (1999, p. 78). Isto é, além das questões oficiais do currículo escolar, é necessário estar atento para a dimensão oculta, percebendo o que está implícito no processo educativo de uma forma geral, como também nas práticas cotidianas de professoras e professores.

As identidades são construídas ao longo da vida dos indivíduos e, nessa construção, combinam-se fatores tanto subjetivos quanto culturais, uma vez que depende das relações estabelecidas (Woodward, 2012). É no contato com as noções de feminino e masculino, expressas principalmente por meio das representações de mulher e de homem, de meninas e meninos, nos discursos, expectativas, valores, hábitos, proibições, entre outros, que as identidades de gênero dos indivíduos vão sendo construídas.

É importante destacar que os sujeitos são constituídos por muitas identidades, seja de classe, etnia, geração, religião, orientação sexual, de gênero, entre outras (Louro, 2010). Neste trabalho, o foco foi direcionado para identidade de gênero, entendida, conforme Butler (2010), como performativamente constituído. 
A intenção do estudo é analisar as concepções de feminilidades e masculinidades produzidas e reproduzidas no contexto escolar e as implicações dessas concepções nas relações de gênero, atentando para a forma como a escola lida com as transgressões de gênero.

A opção por tencionar o currículo para tratar das questões de gênero na escola se deu por entender que as representações de gênero acontecem em todo espaço escolar e a partir de diversos meios. Muitos deles aparecem de forma velada e mascarada por uma falsa naturalidade ou brincadeira sem importância. É importante compreender que o currículo significa muito mais do que um conjunto de normas e conteúdos a serem seguidos e trabalhados, A concepção de currículo vai além do instituído, formalizado. É também experiência, relações, discursos. Currículo é, na verdade, a manifestação da própria função social da escola, é o próprio fazer escolar, estando esse fazer prescrito ou não (Silva, 1999; Lobo, 2005).

Refletir sobre a construção das feminilidades e masculinidades no e pelo currículo é importante, pois entende-se que as representações de gênero acontecem em todo espaço escolar e a partir de diversos meios. Muitas delas aparecem de forma velada e mascarada por uma falsa naturalidade ou brincadeira sem importância, impedindo que se perceba os efeitos de tais práticas, ao mesmo tempo espera-se contribuir com as reflexões sobre gênero e identidade de gênero nos contextos escolares.

A pesquisa empírica foi realizada em uma escola pública municipal de ensino fundamental na cidade de Crato - CE, durante o ano de 2019. A opção foi por um estudo qualitativo, o que permitiu conhecer o cotidiano da escola, seus discursos e suas singularidades. Foram realizadas observações na escola em diversos momentos e espaços específicos. A observação se refere a um momento em que o pesquisador adentra ao ambiente pesquisado e o observa. Essa ação deve buscar a compreensão do cotidiano, percebendo seu ritmo, estrutura, organização, interferências, componentes, relacionamentos, entre outros. Conforme o roteiro de observação, elaborado para o desenvolvimento do estudo, analisamos a escola a partir dos pontos: estrutura da escola (número de salas, materiais, ambientes, cargos e funções, número de alunos, decoração); Projeto Político Pedagógico; projetos que desenvolve; aulas de Educação Física (o que fazem, como é organizada, existe separação das atividades de meninos e meninas, como formam os grupos, como meninos e meninas interagem, transgressões, como as professoras e os professores lidam com as transgressões); hora da merenda (como alunas e alunos interagem na hora do lanche, comem separados ou juntos, existe uma organização dirigida pela escola na hora da merenda, o que conversam); recreio (tempo do recreio, quais ambientes frequentam, o que fazem, do que brincam, como se relacionam uns com os outros, brigas e discussões, intervenção dos funcionários, transgressões nas brincadeiras) e representações de gênero (nas imagens postas na decoração da escola, nas atividades desenvolvidas e nos discursos).

\section{OS RITUAIS DA ESCOLA: CONFORMAÇÕES, NEGOCIAÇÕES E TRANSGRESSÕES DE GÊNERO}

Os rituais estão presentes tanto na escola como em outras instituições sociais e são exercidos desde o momento de entrada até o de saída. Como afirma Lobo (2005), o currículo escolar é posto em prática por meio dos rituais. O toque do sino, expressando o início ou final de determinados momentos; os fardamentos; a separação por ano de estudo e de disciplina; a separação dos banheiros e atividades; a hora do recreio e da merenda; 
as atividades desenvolvidas na sala de aula e os deveres de casa; as avaliações; os elogios e as punições; entre outras situações empreendidas na escola que podem ser caracterizadas como rituais de conformação e de construção de determinado tipo de indivíduo.

Os rituais fazem parte da existência humana. Eles são exercidos cotidiana e repetidamente nos diversos contextos culturais, servindo para demarcar momentos, crenças, mudanças, status. "Somos ontologicamente constituídos por ritual e cosmologicamente formados por ele. Todos nós estamos sob o impacto do ritual" (Mclaren, 1991, p. 70).

É comum pessoas associarem os rituais às práticas místicas, religiosas ou até mesmo a práticas exóticas de sociedades antigas. Porém seu significado é muito mais amplo e é possível perceber a existência deles no dia a dia das pessoas e das instituições sociais como o caso da escola. Conforme McLaren (1991) afirma:

Os rituais se nutrem da experiência vivida; eles germinam no barro das fraquezas humanas e no desejo de sobrevivência e transcendência; eles crescem conjuntamente, a partir das mediações culturais e políticas, que moldam os contornos de grupos e instituições, que servem como agentes de socialização (Mclaren, 1991, p. 73).

Conforme McLaren (1991), a compreensão de um ritual demanda igualmente a compreensão do sistema simbólico que o cerca, "[...] os rituais consistem em conglomerados de símbolos, [...]" (Mclaren, 1991, p. 81). Além da estreita relação com o sistema simbólico, é importante destacar a função de um ritual.

Os rituais servem tanto como as colunas que apoiam a estrutura social urbana, como o substrato que apoia esses mesmos esteios; isto é, os rituais são atributos tanto da infra-estrutura, quanto da superestrutura da sociedade. Em sua ausência, tanto as estruturas familiares, quanto as corporativas entrariam em colapso (Mclaren, 1991, p. 74).

Eles servem, então, como mantedores do funcionamento e das transformações ocorridas nas instituições sociais. A obediência servindo como reprodução, e as desobediências como possibilidades de modificações. Porém, tanto a aceitação quanto a negação acontecem dentro de relações de poder condizentes com os valores e hábitos culturais existentes, que determinam, a partir dos gestos simbólicos, o que é certo e errado, normal e anormal.

Para a efetivação e prática do ritual, se faz necessário um constante processo de manutenção. "A manutenção dos rituais se dá pela experiência repetida cotidianamente, ou seja, cada vez que um ritual é executado, torna-se mais arraigado na cultura local e considerado válido e usual pela pessoa e comunidade" (Lobo, 2005, p. 55). É por isso que uma de suas características principais é exatamente a repetição. Quanto mais repetida a ação, mais enraizada culturalmente se torna e, ainda, pode-se acrescentar, quanto mais repetições, mais naturalizada se torna, o que facilita a conformação dos indivíduos às normas sociais dominantes.

O prestígio dado à escola garante a conformação das fronteiras impostas. Não é cultural questionar o que é ensinado nas escolas, simplesmente porque se acredita na importância disso. Então, a conformação e reprodução do rito se tornam mais fácil. É como afirma Arroyo (2011, p. 46), "quando o currículo, os conteúdos, a sua transmissão e aprendizagem viram um território e um ritual sagrado, tudo fica intocável e inevitável".

Com isso, pode-se afirmar que a função social da escola se cumpre a partir da prática e manutenção dos rituais, com a função de formar determinado tipo de indivíduo 
e de sociedade. McLaren (1991) faz referência aos "Rituais de Instrução" que, quando colocados em prática, são divididos e nomeados de: micro-ritual, macro-ritual, rituais de revitalização, rituais de intensificação e rituais de resistência. Para o autor, os microrituais dizem respeito às atividades desenvolvidas individualmente pelas alunas e alunos no dia a dia escolar. Já os macro-rituais, tratam do conjunto dessas atividades. "Os macro e micro-rituais podem ser compreendidos primeiramente como variações do esquema de rito de passagem" (p. 127). Esses elementos caracterizam o progresso do (a) estudante na vida escolar, passando de um ano a outro, de um assunto menos complexo para um mais complexo, de um status de menina para o de mocinha, de menino para o de rapaz, entre outras mudanças ocorridas a partir das diversas tarefas realizadas nas escolas.

Sobre os rituais de revitalização, esses são atitudes processuais que servem como meio de renovação das responsabilidades dos participantes (Mclaren, 1991). É uma forma de reafirmar o dever de cada membro, assim como também motivar os indivíduos a cumprirem seus deveres. É, assim, um gesto motivacional. E, para o sucesso desse rito de revitalização, se faz necessário uma ação constante e repetida. Essa repetição é o que caracteriza os ritos de intensificação.

A intensificação da norma serve como uma forma de fiscalização e controle, o que se pode associar ao que Foucault (1987) chama de vigilância panóptica, que consiste em um ato de vigilância constante. O sermão, a cobrança, o elogio, a punição, assim como o olhar constante sobre os corpos das alunas e alunos se constituem como rituais que intensificam a importância da obediência à regra e, da mesma forma, à garantia do indivíduo se tornar ou continuar sendo um membro da comunidade.

No entanto, nem todo ritual existente pode ser caracterizado como conformação e obediência à regra. Existem atitudes empreendidas exatamente no sentido de transgressão à norma posta, mesmo quando essa é reafirmada repetidamente. Isso caracteriza os rituais de resistência. Conforme McLaren, eles:

\footnotetext{
[...] emergem como uma série de formas culturais, tanto sutis quanto dramáticas, que compartilham muitas das características de 'inversão simbólica', e invariavelmente se mostram refratários aos dogmas e códigos de conduta autoritários dominantes que são preestabelecidos pelos professores. Os rituais de resistência podem ser adequadamente descritos como um tipo de “desestruturação" cerimonial (1991, p. 128, grifo do autor).
}

Para o autor, negociar e transgredir, nessa situação, é agir ativamente diante do que é imposto, colocando em questão a naturalização das práticas ritualísticas. São formas de adaptar o contexto às especificidades individuais. É imprimir na realidade marcas de subjetividades. É, afinal, fugir da norma.

\subsection{Gênero e práticas educativas}

Pensar sobre como as feminilidades e masculinidades são construídas no e pelo currículo, torna necessário refletir sobre os rituais existentes no meio escolar, destacando como esses reproduzem e produzem noções de gênero no seu cotidiano e nos diversos rituais praticados nas ações rotineiras das escolas.

As reflexões e problematizações em torno da temática de gênero permitiram compreender que o masculino e o feminino são resultados de uma construção histórica e social. Nessa construção, ocorre uma combinação de discursos, símbolos e representações que vão determinando o que é ser homem e o que é ser mulher relativo ao tempo e ao espaço determinado. Também foi possível, a partir do uso do conceito de gênero, refletir sobre as desigualdades existentes entre os sexos, compreendendo que essas são geradas a 
partir de uma organização cultural que determina representações e papéis diferenciados para homens e mulheres. O feminino e o masculino são construídos a partir de uma perspectiva relacional. Segundo Joan Scott (1990), o gênero trata das diferenças percebidas entre os sexos, "o gênero é um elemento constitutivo de relações sociais baseado nas diferenças percebidas entre os sexos, é uma forma primeira de significar as relações de poder" (P. 7). Para a autora, gênero é uma categoria de análise histórica, que permite perceber como as diferenças entre homens e mulheres foram se transformando em desigualdades e como essas relações foram se modificando ao longo dos tempos.

Butler (2010) entende gênero como uma construção social e histórica do masculino e do feminino e como um ato performativo. "[...] gênero não é um substantivo, mas tampouco é um conjunto de atributos flutuantes, pois vimos que seu efeito substantivo é performativamente produzido e imposto pelas práticas reguladoras da coerência do gênero" (Butler, 2010, p. 48). Esse ato performativo significa, para ela, que o gênero não é algo que o indivíduo é, mas sim algo que ele encena ser. Essa encenação ocorre a partir das escolhas que essa pessoa faz nas situações que vivencia, no entanto, essas escolhas não se dão de forma livre, elas são limitadas pelos valores e determinações culturais que são impostas como corretas e verdadeiras. Imposição essa que acontece até mesmo antes do dia do nascimento. O momento em que se descobre o sexo da criança, ainda na barriga da mãe, as expectativas começam a ser traçadas e o futuro desse individuo já começa a ser delineado. "Como sugeriu Preciado, todos estamos já mais ou menos operados/as por tecnologias sociais precisas. Todos somos pós-operados. Não existe corpo livre de investimentos discursivos, in natura. O corpo já nasce maculado pela cultura" (Bento, 2006, p. 107).

A construção de corpos continua por toda a vida do sujeito, como diz Butler, "o gênero é a contínua estilização do corpo, um conjunto de atos repetidos no interior de um quadro regulatório altamente rígido e que se cristaliza ao longo do tempo para produzir a aparência de uma substância, a aparência de uma maneira natural de ser" (Butler, 2010, p. 59).

Ao focar a discussão de ritual considerando as noções de feminilidades e masculinidades, no contexto escolar, pode-se afirmar que são usuais os rituais de conformação, negociação e transgressão. Diferentemente de outros rituais, estes não possuem uma sistematização adequada, com demarcações claras de início e de finalização. A determinação das fronteiras das feminilidades e masculinidades acontece, seguindo a lógica destacada por McLaren (1991) dos micros rituais, empreendidos de forma assistemática e, muitas vezes, implicitamente contemplados em outras atividades.

As feminilidades e masculinidades são, assim, conformadas nos micros rituais na medida em que esses estabelecem as fronteiras do certo e do errado, do normal e do anormal a respeito do que é ser uma mulher e um homem. Acontecem a partir da existência de diferenciações na forma de tratar meninas e meninos, nas expectativas lançadas, nos espaços destinados a cada um, na forma de avaliar, na forma de representar meninas e meninos, homens e mulheres. Acontecem também na medida em que as regras de bom comportamento e os deveres das alunas e alunos são reafirmados. Isso ocorre no ato de elogiar, de punir e na imposição de papéis sociais. Acontecem quando as desigualdades entre os sexos são justificadas e quando essas são igualmente ignoradas, entre outras situações que podemos caracterizar como rituais de revitalização e de intensificação de gênero.

Mas é também a partir dos rituais, mais especificamente nos rituais de resistências, que as negociações e as transgressões acontecem. Os sujeitos agem e reagem diante das diversas situações vivenciadas e a conformação feminina ou masculina, algumas vezes, é negociada, questionada, reinventada, outras vezes, é simplesmente negada, transgredida. 
Deste modo, é possível afirmar que os rituais praticados nas escolas, sejam de conformação, sejam de resistência, constroem as noções de feminilidades e masculinidades e essas noções exercem uma influência fundamental na formação das identidades de gênero das alunas e alunos.

\title{
2 FEMINILIDADES E MASCULINIDADES NO COTIDIANO ESCOLAR
}

As feminilidades e masculinidades são construídas no cotidiano escolar, basta olharmos para os diversos rituais que os compõem. E foi exatamente nessa busca que foram desenvolvidas observações. No processo de observação do cotidiano de uma escola pública de Ensino Fundamental, foi possível presenciar cenas do cotidiano envolvendo discursos e representações de gênero.

As observações ocorreram em todos os espaços da escola, nos momentos de recreação, hora do recreio, sala de leitura (lugar de registro das ocorrências) e no pátio da escola (lugar das interações em grupo). Observar o cotidiano de uma escola consiste em uma atividade de estranhar o naturalizado, estranhar aquilo que está diante dos olhos cotidianamente, e que já foi incorporado como comum. É um exercício que vai além de simplesmente ver a escola, é preciso olhá-la. E olhar, nas palavras de Laplantine (2004):

\begin{abstract}
[...] consiste numa reiteração daquilo que se encontra diante de nós e a visibilidade, enquanto forma primeira de conhecimento, afeta-nos ao mesmo tempo em que nos sentimos afetados por aquilo que (a) percebemos. Trata-se de uma visibilidade não apenas ótica, mas também tátil, olfativa, auditiva e gustativa que nos conduz a deixar de opor o "diante" e o "atrás", o "fora" e o "dentro", para compreender a natureza dos laços que ligam um "diante" que nós incorporamos e um "atrás" a partir do qual se efetua a atividade sensitiva assim como intelectual (Laplantine, 2004, p. 20, grifo do autor).
\end{abstract}

A instituição pesquisada é uma Escola municipal localizada no centro da cidade do Crato, localizada na Região Metropolitana do Cariri, ao sul do estado do Ceará. Atua na modalidade do Ensino Fundamental I (do $3^{\circ}$ ao $5^{\circ}$ ano) e Ensino Fundamental II (do $6^{\circ}$ ao $9^{\circ}$ ano), sendo esse ofertado em tempo integral. Funciona nos períodos matutinos e vespertinos, recebendo alunas e alunos oriundos tanto do bairro onde a escola está inserida, como também de outras comunidades do município. Nos primeiros dias de observação, a atenção foi direcionada para a estrutura física da escola. Esta é composta por espaços amplos e arejados, contendo: salas de aula, sala da diretoria, sala da coordenação, secretaria, cantina, sala de leitura, laboratório de informática, biblioteca, quadra de esportes, sala dos professores e banheiros.

\subsection{As brincadeiras no recreio e nas aulas de recreação}

Durante as observações no recreio e nas aulas de recreação, foi possível perceber meninos brincando de futebol, meninas de corda, meninos de dama, outros meninos e meninas brincando de boliche, alguns parados no pátio conversando, outros correndo atrás de outros, alguns meninos brincando de luta. Também foi detectado, principalmente entre os alunos do ensino fundamental I, uma separação entre meninas e meninos durante as brincadeiras e, apesar de estarem no mesmo espaço, havia pouca interação entre eles. Em relação ao ensino fundamental II, percebe-se uma maior interação entre alunas e alunos. As brincadeiras diminuem, principalmente para as meninas, que na sua maioria, ficam conversando em pequenos grupos. Nesses grupos, é perceptível a interação entre meninas e meninos. E apenas alguns meninos estavam brincando de futebol. 
Assim que a sirene dispara, as alunas e alunos saem das salas correndo em direção ao pátio. A maioria vai em direção à cantina buscar a merenda, já outros (as) vão direto brincar. As brincadeiras observadas foram: correr, pega-pega, esconde-esconde, pular corda, de dama, boliche, elástico e outros brinquedos que ficam no pátio à disposição dos (as) alunos (as). Logo, os demais que estavam comendo vão também aproveitar os minutos de intervalo. Os recreios são divididos, primeiro é o intervalo dos estudantes dos anos iniciais do Ensino Fundamental e, só após a finalização desse, tem início o intervalo das alunas e alunos dos anos finais do Ensino Fundamental. As cenas relatadas a seguir foram registradas no recreio e nas aulas de recreação.

$>$ Recreio

- $1^{\mathrm{a}}$ Observação

Nos primeiros dias de aula, alguns brinquedos como dama, boliche, baralho, eram disponibilizados aos estudantes. No dia observado, não havia nenhum desses brinquedos no pátio. Mas, mesmo assim, os (as) alunos (as) encontraram maneiras de brincar. Foram observados grupos de meninas e meninos que brincavam separados. Ou seja, só meninas e só meninos. Mas houve também outros que brincavam juntos, como na brincadeira de polícia e ladrão, em que não houve separação entre elas e eles, nem no momento da divisão dos dois grupos (quem seriam os polícias e quem seriam os ladrões). Além do pátio, verificou-se que algumas alunas e alunos se dirigem na hora do recreio para a quadra da escola, com a supervisão de um funcionário que de longe acompanha as brincadeiras. Assim como no pátio da escola, foi possível perceber muitas brincadeiras acontecendo ao mesmo tempo. Alguns meninos brincavam de futebol enquanto outros brincavam de outra coisa que foi difícil de identificar à primeira vista. Essa brincadeira contava com a participação de meninos, na sua maioria, e poucas meninas (aproximadamente quatro alunas e uns sete alunos). Nela, os meninos corriam atrás das meninas e as levavam até a trave da quadra. Tratava de uma espécie de futebol, sendo as meninas a bola do jogo. Os meninos tinham que conseguir segura-las e leva-las para fazer gol. Após ser capturada, a menina era levada até a trave, em média quatro meninos seguravam e carregavam, pelos braços e pernas. E essa, por sua vez, tentava se soltar, chutando os meninos. Após conseguir capturar todas as meninas, essas reivindicaram que seria a vez delas correrem atrás deles. Os meninos resistiram dizendo que elas não teriam chance, pois eram mais rápidos e em maior número. As meninas insistiram até que o jogo se inverteu. As meninas começaram a capturar os meninos, mas como a quantidade de meninos era maior, elas apresentavam dificuldades para realizar a captura.

- $2^{\mathrm{a}}$ Observação

No início do intervalo, duas alunas (em média 12 anos de idade) se aproximam do funcionário e pedem a corda. Ele diz que não vai dar porque fazem muita bagunça e demoram a retornar para a sala de aula. Elas insistem e prometem se comportar. Ele atende ao pedido e informa que se fizerem bagunça a corda será guardada. No momento em que elas pegam a corda, outras meninas já aparecem para participar da brincadeira. Nesse início, ficam brincando cinco meninas, duas seguram a corda e as três pulam ao mesmo tempo. Depois ocorre um revezamento. Poucos minutos depois, outras meninas aparecem para brincar também, assim como um menino chega para pular corda e é aceito por todas. Depois de alguns minutos ele pede para girar a corda enquanto elas pulam. Ele começa a girar a corda e depois de alguns segundos começa a girar muito rápido, de forma que nenhuma das meninas consegue mais pular, acabam caindo. Uma das meninas tomou a corda da sua mão e disse que ele não ia mais brincar. Porém ele não aceitou e disse que ia continuar. Pegou a ponta da corda e puxou. A menina não aceitou e, segurando a corda, 
deu um chute na perna dele. O menino foi para cima dela e ameaçou dar um soco. Ela protegeu o rosto com as mãos e gritou. As outras meninas, vendo o que estava acontecendo, foram para cima dele e todas juntas conseguiram fazer com que ele soltasse a corda e se afastasse do grupo. $\mathrm{O}$ garoto foi em direção ao funcionário e relatou que as meninas não o deixam brincar. Indo até a turma que estava pulando corda, o funcionário diz: "deixem ele brincar! Vocês não querem direitos iguais? Então...". Uma delas diz: "ele me bateu e não tava rodando a corda direito". O funcionário fala: "não se pode bater em mulher, nem com uma flor. Continuem a brincar e se começarem a brigar eu tomo a corda".

$>$ Aulas de recreação

- $1^{\text {a }}$ Observação

A professora iniciou a aula formando um círculo e solicitando a repetição de movimentos para se alongarem. Uma menina, na medida em que realizava os movimentos ordenados, batia com a mão na cabeça de um aluno próximo a ela. Toda vez que a professora pedia para esticar os braços para cima, na descida, a aluna proferia um tapa na cabeça do colega. A professora, vendo isso, disse: "Para com isso (falou o nome da aluna), deixa de enxerimento", o que despertou o riso dos demais e alguns outros meninos disseram: "tão namorando" (e mais risos). A aluna, envergonhada da atenção chamada, saí de perto do menino e vai em direção a uma aluna e continua o alongamento. Depois, a professora entrega a bola a um aluno que rapidamente se dirige para o outro lado da quadra, acompanhado de um grupo de outros alunos e começaram a jogar futebol. Do outro lado da quadra, todas as meninas da sala e alguns outros meninos que não foram jogar futebol começam a se organizar. A professora entrega uma corda para dois alunos e os demais formaram uma fila e começaram a brincar. Foi observado que a divisão dessas brincadeiras e desses grupos eram corriqueira na aula de recreação, pois tudo aconteceu rapidamente, sem necessitar de muita intervenção e orientação da professora. A brincadeira de corda e futebol continuou, até que uma aluna diz que prefere brincar de elástico. A professora entrega o elástico para essa aluna, ela se afasta e chama mais duas colegas para brincar com ela. Durante a brincadeira, um dos alunos que estava pulando corda se aproxima das meninas brincando de elástico e as observa por uns minutos. Depois saí e retoma para a brincadeira de pular corda.

\section{- $2^{\mathrm{a}}$ Observação}

A professora inicia orientando os alunos e alunas a fazerem uma roda e iniciar movimentos para alongamentos. Após esse momento, tem-se o aquecimento com uma brincadeira de corrida. O objetivo era chegar do outro lado da quadra, bater na mão da sua dupla de corrida, e essa, por sua vez, voltaria para o início, quem chegasse primeiro ganharia a partida. Essa brincadeira aconteceu com meninos e meninas ao mesmo tempo. Eles e elas disputavam entre si. As duplas foram formadas pela escolha dos próprios alunos e alunas, sem a intervenção da professora. A única recomendação foi formar uma parceria com um colega. Acabou que as meninas formaram duplas apenas com as meninas e os meninos formaram duplas apenas com os meninos. No final, sobrou um menino e uma menina. O menino, vendo que nenhum outro colega faria dupla com ele, se afastou do grupo e sentou em um canto da quadra. A menina disse à professora que estava sem dupla. A professora responde: forme trio com as meninas (apontou para uma dupla a sua frente), vocês revezam. Numa partida, duas correm e uma torce, na outra partida uma sai para torcer e outra entra no lugar. A professora não explica o motivo de não orientar a menina a formar dupla com o garoto que estava sem par. Agiu como se não tivesse sequer percebido que sobrou um aluno. O aluno, por sua vez, permaneceu sentado no canto da 
quadra e não reivindicou sua participação na brincadeira. Assim que finalizou essa primeira atividade, a professora entregou a bola para um aluno e a corda para outro. Foram formados os dois grupos sem necessitar orientação da professora para a divisão. Alguns meninos foram jogar futebol num canto da quadra e o restante da turma (meninos e meninas) foi pular corda. Nessa equipe da corda, a maioria é de meninas. Os meninos se constituem como minoria, uma vez que os demais vão jogar futebol. O jogo do futebol é organizado pelos próprios alunos. São eles quem fazem a divisão das duas equipes para o jogo e quem ditam as regras (quem vai chutar quando é falta, etc.). A professora só interfere no jogo quando percebe que os alunos podem se machucar. Vez ou outra ela grita de longe: "cuidado com essa bola, tão chutando forte demais", "cuidado para não machucar o colega", entre outras frases para chamar atenção dos alunos.

\subsection{Os registros de ocorrência}

Um ritual observado na escola foi o registro de ocorrência. Trata-se de uma prática de controle e disciplinamento de corpos e comportamentos de meninas e meninos, tal qual uma delegacia, são realizados registros inspirados em boletins de ocorrência. As ocorrências são registradas em um livro que fica guardado dentro da sala de leitura. Toda vez que uma aluna ou aluno se comporta de maneira a infringir alguma regra, é levado para essa sala para o registro da ocorrência. Lá dentro, uma funcionária e um funcionário são responsáveis por tratar desses casos. Essas duas pessoas são professores da instituição, que, por motivos de saúde, se encontram afastados da sala de aula. No momento da realização da pesquisa, prestavam auxílio à gestão da escola, no contato direto com os estudantes. No recreio, ficam o tempo todo interagindo com os estudantes, conversando sempre, chamando atenção quando as crianças estão correndo perigo de se machucar, chamam pelo nome de cada um, o que mostra certa familiaridade. Também são responsáveis pelos registros de ocorrência. Essas duas pessoas foram fundamentais para a pesquisa por estarem em contato constante com os estudantes, docentes e gestão. Eles relataram a difícil relação da família com a escola. "Muitas vezes ela (a família) não entende nossa postura diante de algumas questões e vem reclamar, até ameaças de processo já recebemos de pais de alunos". Relata ainda que um dia uma mãe veio reclamar com a diretora por conta da suspensão do filho. Diz que a escola não permite relações de namoro e o filho dessa senhora foi pego namorando. Ele disse: "Ela pensa que o filho é um santo, que vem para escola para estudar, mas na verdade ele vem é beijar as meninas, já agarrou muitas aqui, e a escola não permite essas atitudes".

Ao analisar a questão e ao se referir às meninas, o funcionário fala: "tem menina que também facilita, olha como vem para a escola" (faz um movimento com a cabeça mostrando duas alunas que passavam no momento). As duas, com 12 ou 13 anos de idade, estavam maquiadas, com batom vermelho, sombras nos olhos, calças justas e uma delas com a blusa da farda dobrada de forma em que a barriga ficava à mostra.

Nesse momento, ele relata que está preocupado com a grande quantidade de casos de violência contra a mulher na região e diz que a última vítima era conhecida dele. Argumenta que as mulheres facilitam, nos casos de estupro, pelas roupas que usam. Disse que cada roupa tem seu lugar de usar e shorts curtos e decotes não são roupas para serem usadas em locais públicos, por chamar atenção dos homens. "Isso facilita a ação dos aliciadores", afirma ele.

Geralmente os casos de indisciplina são tratados seguindo os mesmos passos: inicia com uma conversa com o(a) aluno(a), pede que ele ou ela explique o que aconteceu, registra a ocorrência e pede que o(a) estudante assine o livro. Durante essa conversa, os funcionários relatam algumas regras da escola a depender do caso registrado, enfatizando 
o erro cometido, fazendo também com que o(a) estudante prometa não se comportar mais daquela forma.

Em alguns casos, é possível ver um tom amigável nessa conversa, demostrando certa tolerância com o ocorrido, assim como também expressando uma confiança de que a situação não se repetirá. Mas, em outros casos, a aluna ou aluno é submetido a uma pressão, com ameaças de chamar os familiares ou até mesmo expulsão da escola. Nesses casos, os funcionários demonstram indignação com o fato registrado, expressando a não tolerância se o caso vier a se repetir. Nas ocorrências observadas na escola, relatadas a seguir, foi possível detectar cenas e diálogos demonstrado a forma como percebem as masculinidades e feminilidades.

A primeira ocorreu logo após o primeiro intervalo. A funcionária entra na sala de leitura juntamente com três alunas (aproximadamente 9 anos de idade), do $4^{\circ}$ ano. Todas sentam e, já com o livro de ocorrência aberto, a funcionária pede explicação sobre o atraso na entrada da sala de aula após o término do intervalo. As três meninas entraram na sala demostrando certo medo e vergonha. Uma delas pediu para não registrar a ocorrência, justificou que não haviam percebido que o sinal tocou porque estavam brincando de esconde-esconde. A funcionária diz: "vou fazer o registro para a próxima vez vocês ficarem atentas ao sinal. Tocou, tem que ir para sala". Ela ressaltou que se tratava do primeiro registro das meninas, afirma que se tiver mais de três registros só entra com a presença dos pais ou responsáveis. O tom na voz da funcionária era amigável e demostrava confiança de que o caso não ia se repetir. As meninas, assim, prometem não mais se atrasar, assinam a ocorrência e voltam para sala de aula. Minutos depois da saída das meninas, um funcionário entra na sala de leitura e pergunta para as outras funcionárias da sala: “E aí meninas, já tivemos algum B.O. hoje?". Elas respondem que sim e relatam o ocorrido com as três alunas. Percebe-se que chamar as ocorrências de B.O. é uma brincadeira adotada pelos funcionários da escola fazendo alusão ao Boletim de Ocorrência registrado nas delegacias de polícia. Após escutar o relato da ocorrência, o funcionário diz: "Vou ali atrás de mais algum B.O!". Ficou perceptível que o registro das ocorrências é algo prazeroso para os(as) funcionários(as), esses se divertem compartilhando os casos de indisciplina das alunas e alunos, assim como também demostram frustação quando o caso não é considerado grave, como no caso das três alunas que apenas se atrasaram para a aula.

A segunda ocorrência envolveu uma aluna (de aproximadamente 13 anos de idade). A funcionária imediatamente pergunta como a aluna está, demonstrando, nessa forma de cumprimento, certa familiaridade, como se já fosse comum a estudante ir até a sala de leitura para conversar. A aluna responde: "eu fui conhecer meu pai ontem". Uma das funcionárias de forma um pouco surpresa pergunta: "e como foi?". Depois de alguns minutos conversando sobre como chegou até seu pai, a aluna chamou uma das funcionárias dizendo: "vem aqui me dá um abraço". A funcionária abraça a aluna e diz: "tão linda, deveria ser mais direitinha". A menina diz: "sou direita sim" (risos). Nesse momento o funcionário entra na sala e olha para a aluna e pergunta: Qual teu B.O. hoje? "Graças a Deus, nenhum", responde ela em tom de riso. "Tem certeza"? Insiste ele. "Tenho! Quantos eu já tenho"? Indaga ela. "Vários, tenha cuidado"! Responde o funcionário.

A terceira ocorrência acontece com um aluno (aproximadamente 13 anos de idade), o funcionário manda o menino sentar e aguardar. A funcionária entra e pergunta do que se trata. Ele responde dizendo que, do aluno, ele cuida. $\mathrm{O}$ aluno permanece sentado em uma das cadeiras da sala, aparentemente com raiva, braços cruzados e olhar fixo em direção à porta. Após aguardar alguns minutos, diz "eu quero voltar para a sala, não fiz nada". Após alguns minutos de espera, o funcionário vai até o aluno e pede que se 
explique. O aluno, por sua vez, sem muitos rodeios, simplesmente diz que não fez nada. É argumentado que a professora relatou que o aluno chamou o colega de corno. O aluno rebate dizendo que não chamou. $\mathrm{O}$ aluno é instigado a confessar, pois o funcionário afirma que a professora seria incapaz de inventar algo. Diante da não confissão, o caso é registrado e o aluno alertado que da próxima vez ele só entra com um responsável. É solicitado a permanecer na sala. Como castigo, não assistirá mais ao restante da aula do dia. A funcionária que acompanha toda a conversa entre aluno e o colega de trabalho faz uma comparação entre os comportamentos de meninas e meninos. Diz que as meninas compreendem bem mais rápido, referindo-se à obediência; já os meninos precisam de ameaça para obedecer a uma ordem.

A quarta ocorrência aconteceu após um barulho vindo do pátio. A funcionária entra na sala de leitura muito nervosa, junto com ela entram dois alunos (de aproximadamente 8 anos de idade), o funcionário, percebendo o nervosismo da colega de trabalho, manda os dois alunos sentarem e informa que vai resolver o caso. Inicialmente, o funcionário pede para os alunos tirarem par ou ímpar, para saber quem vai falar primeiro. O primeiro a falar diz: "foi ele quem começou". O segundo, por sua vez, nega, afirmando que quem começou foi o outro. E, por alguns minutos, permaneceram um culpando o outro.

Os alunos são alertados sobre a quantidade de ocorrências permitidas e o que acontece quando se extrapola o limite de três registros, que no caso é chamar um responsável pelo aluno. O livro de ocorrência, aberto em cima da mesa, era constantemente alvo do olhar dos alunos, sempre que possível o responsável pelos registros direcionava sua atenção para o livro, apontando para suas páginas, levantando para dar uma ênfase maior, reafirmando que, se registrasse o caso, não tinha mais como voltar atrás com a ocorrência contabilizada no total permitido por aluno. Os alunos aceitaram a proposta, apesar da resistência de um deles em estender a mão para cumprimentar o colega. Ao perceber a resistência do menino o funcionário diz: "o que é isso? Não é homem não? Aperte a mão do colega e peça desculpas pra ele também". O aluno, mesmo sem graça e expressando pouco conforto em fazer isso, obedeceu às ordens. Só após a saída dos alunos, a questão ficou esclarecida. Um chamou o outro de "viadinho", esse ofendido deu um soco nas costas do colega. Tudo isso aconteceu no início da aula, vendo a briga, o professor, que estava em sala no momento, chamou a funcionária e pediu que os levassem à sala de leitura, local em que ocorrem os registros de ocorrência.

A quinta ocorrência surge logo depois de alguns minutos da anterior. Uma aluna (de uns 10 anos) e um aluno (com aproximadamente 8 anos). $\mathrm{O}$ aluno chutou uma bola no rosto da aluna na hora do recreio. A menina foi reclamar, para a professora, que estava com o rosto doendo. $O$ funcionário ao iniciar a conversa abre o caderno, olha para o aluno e diz: "se eu pegasse uma bola e jogasse na sua cara, você ia gostar?". O aluno surpreso diz que não. Os casos de indisciplina do aluno, no ano anterior, são relembrados e ele é alertado de que não era nem pra estar na escola esse ano. $\mathrm{O}$ aluno permanece calado e com a cabeça baixa. A aluna explica o que aconteceu após ser solicitada, diz que estava com duas amigas brincando e ele estava jogando bola com outros colegas. Ele pediu para elas se afastarem porque estava atrapalhando a brincadeira e elas se negaram. Ele, com raiva, chutou a bola que pegou no rosto da menina. Ao ouvir o relato da aluna, o menino intervém e diz: "eu chutei a bola porque vocês vieram pra cima de mim pra me bater". Ela confirma e diz: "fui pra cima dele porque ele disse que eu tava 'queixando' ele". O termo "estar queixando" não é entendido e a aluna explica. Estar "queixando" significa dar em cima de alguém, paquerar, se mostrar interessada em alguém, explica a aluna. Diante da resposta, o responsável pelo registro da ocorrência diz em tom sério: "homem que é homem não diz 
gírias, rapaz, isso é muito feio! Quem é capaz de dizer isso, é capaz de dizer outras coisas também, não fale mais assim". O aluno já estava com muitas ocorrências, prestes a ser expulso da escola. Ele sempre muito calado, cabeça baixa, pernas balançando, sorriso entre dentes, o que expressava certa timidez e nervosismo. Só falava algo quando era solicitado. A menina já se mostrava mais segura nas palavras, olhar fixo e sério. O menino é solicitado a pedir desculpas para a colega, ele reluta, mas acaba cedendo diante da fala do funcionário. "pegue na mão da colega, você não é homem não para pegar na mão de uma mulher?".

A sexta ocorrência envolveu uma menina e um menino (os dois com aproximadamente 12 anos). A menina explica que outra aluna da mesma turma tinha ameaçado bater nela. A aluna é chamada para a conversa e, ao chegar na sala, se joga na cadeira, que tinha sido indicada. Ao sentar, seu corpo ficou todo curvado, como se quisesse se deitar na cadeira. Logo ela é repreendida. "Senta direito, você já é uma moça" diz a funcionária. Ela, por sua vez, se acomoda de forma ereta na cadeira. O ritual sempre começa com a explicação sobre o livro de ocorrência e as consequências que o excesso de registro pode causar. A aluna é solicitada a relatar o caso. Ao explicar a situação, a menina chama a colega pelo apelido, momento que é reprendida: "não chame sua colega por um apelido, isso é coisa de presidiário. Se alguém te apelidar você vai gostar? Vocês têm nomes bonitos, para quê apelidar? Isso é feio". As meninas são alertadas que devem se cuidar pois serão as futuras cidadãs cratenses. A funcionária enfatiza a importância de estudar para conquistar a independência financeira, não querer saber de namoro agora e nem ficar dependendo de homem para sobreviver. Diz: "estudem para conseguir um bom trabalho, ter seu dinheiro e não depender de marido". Em seguida, passa a palavra novamente para a aluna continuar explicando o que tinha levado sua colega a proferir uma ameaça. A menina diz que ficou sabendo que a sua colega de sala havia dito que iria bater nela na hora da saída, quando ninguém estivesse vendo. A outra aluna interfere e nega ter proferido a ameaça. Ao ser indagada sobre quem havia dito isso, ela diz que foi seu colega de sala (o aluno que a acompanhava no momento) e aponta para ele. Nesse momento, o aluno, aparentemente nervoso, afirma que a ameaça aconteceu de verdade. A resposta do garoto não foi aceita de imediato, o que demostrou desconfiança que o garoto teria inventado a ameaça. Sem ter a confissão do menino, o funcionário disse: "Assuma, homem que é homem assume o que faz, quando não assume é outra coisa". Ao ouvir isso, o aluno fica surpreso e acaba assumindo que inventou a ameaça. E logo é elogiado. "Parabéns, homem que é homem age assim, você não foi covarde, assumiu o que fez, não farei o registro do caso porque você foi corajoso e assumiu a culpa". Quando as alunas e o aluno saíram da sala de leitura o funcionário diz: "agora posso rir. Fico me segurando para não rir na frente deles para não perder a moral, mas a vontade de rir é grande" (risos). Disse também que o papel dele é como uma espécie de delegado, às vezes o registro do caso não é necessário, por isso faz a conciliação entre as partes. Porém, outros casos, segundo ele, se fazem necessário o registro, até como uma forma de formalizar os atos de indisciplina na escola, servindo de registro para mostrar à família ou às autoridades, caso seja necessário.

A sétima ocorrência acontece no final do primeiro recreio, uma aluna se aproxima chorando muito e diz que um colega o havia batido. O garoto é chamado e indagado: "você bateu nela?". Ele reponde que sim. O funcionário continua, "você é pai dela?", "Não", responde o aluno. "É irmão dela?". "Não". "É marido dela?". "Não", responde novamente o menino. "Então por que você bateu nela? Qual é o seu direito? Não faça mais isso e peça desculpas.” Após o pedido de desculpas, os dois são liberados.

Para finalizar o relato dos casos observados, é interessante apresentar uma conversa presenciada entre diretora e aluno. A gestora da escola estava conversando com um senhor, aparentemente responsável por algum estudante, alguns minutos depois, 
aproxima-se um aluno tocando no braço da diretora, chamando sua atenção. A funcionária, percebendo a presença do garoto, interrompe a conversa com o senhor e pergunta para o menino: “O que aconteceu?". Ele respondeu dizendo que uma colega o havia batido e ele veio fazer uma reclamação sobre o fato. Ouvindo isso, a diretora indaga: "o que? Uma garota bateu em você? Uma menina? Que homem fraco é você que deixa uma menina te bater? Sente aí que vamos conversar daqui a pouco".

\section{ENTRE BRINCADEIRAS E REGISTROS DE OCORRÊNCIAS: UMA ANÁLISE DAS NEGOCIAÇÕES DE GÊNERO}

A escola, por tudo já destacado, produz e reproduz, o tempo todo, noções de feminilidades e masculinidades. Noções essas que vão sendo, a partir dos diversos rituais, incorporadas no imaginário dos estudantes, influenciando seus comportamentos, percepções, expectativas, entre outras questões relativas à identidade dos sujeitos. Essa incorporação acontece dentro de um espaço de relações e negociações, onde os estudantes trazem para a escola noções de gênero, incorporados em outros espaços, assim como também trazem aspectos de sua subjetividade, o que permite perceber que eles também participam dessa produção e reprodução. "Evidentemente, os sujeitos não são passivos receptores de imposições externas. Ativamente eles se envolvem e são envolvidos nessas aprendizagens, reagem, respondem, recusam ou as assumem inteiramente" (Louro, 2010, p. 61).

Nesse processo de produção e reprodução de gênero, as feminilidades e masculinidades vão sendo afirmadas, vigiadas e negociadas. Essa negociação acontece dentro de uma organização marcada pela regra, pela hierarquia e, em alguns casos, pelo autoritarismo, fazendo com que algumas vozes não tenham a mesma importância que outras ou até mesmo não sejam consideradas.

As cenas observadas, e já relatadas anteriormente, mostram esse processo de negociação acontecendo, principalmente, entre funcionários e estudantes, e expressando tanto quais são as noções de gênero afirmadas e vigiadas, como também as hierarquias nas negociações. A presença constante de funcionários em toda a instituição, até na hora do recreio, evidencia a importância das regras e da obediência. O conceito de vigilância panóptica (Foucault, 1987) contribui para a compreensão desse processo de disciplinamento dos indivíduos que acontece no espaço educacional.

A vigilância panóptica se refere a uma estrutura construída com a intenção de vigiar indivíduos, seja em uma prisão, em um hospício ou até mesmo em uma escola, na tentativa de controlar suas ações por meio exatamente desse olhar constante. As regras de comportamento e convivência são lançadas e cobradas aos indivíduos. E esses, por sua vez, precisam atender às expectativas dos vigilantes para permanecerem como um membro da instituição. "Daí o efeito mais importante do Panóptico: induzir no detento um estado consciente e permanente de visibilidade que assegura o funcionamento automático do poder" (Foucalt, 1987, p. 164).

Essa vigilância e negociações foram percebidas tanto nas brincadeiras e aula de recreação, quanto nos registros das ocorrências observadas na realização desta pesquisa.

As brincadeiras constituem-se como atividades importantes para 0 desenvolvimento da criança. Esses momentos lúdicos proporcionam interação e, ainda, exercitam a mente, o corpo e as emoções. "As crianças, capazes de múltiplas relações, estão a todo momento experimentando diferentes formas de brincadeira, buscando novos prazeres, fazendo coisas movidas pela curiosidade e vontade de conhecer o mundo" (Finco, 2003, p. 96). 
É também por meio da brincadeira que papeis sociais são afirmados e reproduzidos. Certas formas de brincar servem como preparação para a vida real. O brincar de boneca, de escolinha, de carrinho permite à criança interpretar situações reais do seu dia a dia, ocupando outro papel. Elas imitam os pais e mães, outros familiares, as professoras e os professores, simulam ser alguém que viu na revista ou passou na televisão.

Logicamente, no ato de brincar, a imaginação da criança não está presa, obrigatoriamente, às situações reais do dia a dia e nem muito menos ao brinquedo. Mas muito do que a criança experimenta e vivencia no seu cotidiano é reproduzido no brincar. E esse ato de interpretar situações reais gera aprendizagens sobre o que é ser um homem e uma mulher. Quando a menina é direcionada a brincar de boneca e o menino de bola, além de ocorrer uma separação entre as brincadeiras, acontece também uma demarcação de lugares e papeis sociais. "A expectativa de que aos meninos cabem atividades mais excitantes que exigem força, agilidade e destreza, encontra paralelo na ideia, segundo a qual as meninas preferem ficar sentadas, ou brincando de roda, ou cantando canções de ninar [...]" (Toscano, 2000, p. 64).

Assim, percebe-se a existência de uma distinção entre "brincadeiras de meninas" e "brincadeiras de meninos" na nossa sociedade. Essa divisão se dá exatamente nas brincadeiras que proporcionam a simulação de situações reais do cotidiano, como cuidar da casa, dos filhos, dirigir, jogar futebol, para citar alguns exemplos, sendo essas demarcadas a partir de noções de feminilidades e de masculinidades aceitas como corretas.

$\mathrm{Na}$ escola investigada, essa cisão também foi percebida e, apesar do olhar constante dos funcionários, as divisões ocorriam de forma espontânea, sem a necessidade de muitas intervenções diretas dos profissionais nas brincadeiras. Elas e eles iam buscando seus pares e escolhendo suas formas de brincar. Mas, de forma alguma, isso significa liberdade de escolha, pelo contrário, significa que as regras impostas na separação do brincar da menina e do menino já se encontravam enraizadas e naturalizadas no cotidiano da instituição, assim como também no cotidiano de outros espaços frequentados pelos estudantes.

No entanto, verificou-se também a prática de brincadeiras realizadas com a interação de meninas e meninos, como pular corda e a brincadeira de captura das meninas, já relatada em tópico anterior, o que pode ser explicado por uma possível desconstrução das demarcações e separações em algumas atividades, ocasionadas, principalmente, pelas negociações de gênero que também são construtoras de noções de feminilidades e masculinidades. Como também pode ser explicada pela ideia de que existem determinadas brincadeiras que são consideradas neutras, podendo ser brincadas por meninas e meninos.

Nos registros das ocorrências, a demarcação e vigilância das fronteiras de gênero ficaram mais evidentes. É importante ressaltar que o ato de fazer o registro escrito dos casos de indisciplina revela a estratégia usada pela escola para controlar os discentes e garantir a norma da instituição, servindo tanto para os funcionários, no trato dos casos de indisciplina, como também para gerar, nas alunas e alunos, o medo do registro, inibindo certos comportamentos.

Essa estratégia praticada pela funcionária e funcionário da escola segue uma sequência de intervenção e controle para a garantia da norma com ênfase muito mais no registro do que na própria regra. No trato dos casos, as regras infringidas não eram postas em questão, nem muito menos refletidas. Acontecia apenas uma demarcação da infração e uma tentativa de controle, como aconteceu no caso, já relatado, do aluno chamado de "viadinho". Nesse fato, o funcionário não chegou sequer a mencionar isso no diálogo 
travado com os alunos, simplesmente age no intuito de conciliar as partes e garantir o funcionamento "normal" da instituição, desconsiderando as questões envoltas nesse ato ofensivo e as implicações disso, caso a ofensa não cesse.

As normas existem em todas as instituições sociais e possuem funções fundamentais na garantia do bom funcionamento, da justiça, da ordem, do bom conviver, entre outras questões. Na escola, assim, as regras se fazem necessárias para o desempenho institucional. Elas são importantes. O problema é quando elas são impostas aos sujeitos, sem reflexão e sem consciência da sua função e intenção. Discursos como: "se você se comportar assim mais uma vez, vou fazer o registro"; "vou registrar seu atraso dessa vez para que dá próxima você não se atrase mais"; "se passar de três registros você vai ser suspenso"; entre outros enunciados proferidos, demonstram que a via encontrada para o controle e manutenção da ordem é o medo da consequência e não a conscientização dos danos causados pelo ato em si.

Também é importante destacar que a estratégia usada no registro de determinados comportamentos das alunas e alunos é usado como meio de lidar com os casos de infrações, mas serve da mesma forma para demarcação e reprodução de gênero. Ao lidar com os casos, a funcionária e o funcionário se valiam de sermões, delimitando fronteiras e pertencimentos da menina e do menino.

As falas: "elas facilitam a ação dos aliciadores"; "tão linda, deveria ser mais direitinha"; "as meninas são mais compreensivas"; "senta direito, você já é uma moça"; "estudem para conseguir um bom trabalho, ter dinheiro e não depender de marido"; "homem que é homem assume o que faz, quando não assume é outra coisa"; "se você não é parente dela, qual o seu direito de bater nela?"; são exemplos de discursos reprodutores de feminilidades e masculinidades proclamados nas situações observadas.

De acordo com Meyer (2008), "a escola (como muitas outras instituições sociais) investe muito de seu esforço na elaboração e na implementação de mecanismos e de estratégias que objetivam uniformizar os indivíduos que a compõem" (p. 22, grifo do autor). Esse processo de padronização não ocorre de forma explícita e direta. Ao contrário, ocorre de forma muito sutil e contínua, que em meios às atividades cotidianas podem passar até despercebidas. "Os sentidos precisam estar afiados para que sejamos capazes de ver, ouvir, sentir as múltiplas formas de constituição dos sujeitos implicadas na concepção, na organização e no fazer cotidiano escolar" (Louro, 2010, p. 59).

$\mathrm{O}$ enfoque dado à manutenção da ordem, por parte desses profissionais, revela ainda a forma como a escola atua e percebe a diferença. Conforme Candau (2011), as instituições de ensino vêm, historicamente, desconsiderando e inibindo a diferença. $\mathrm{Na}$ sua prática diária, a organização escolar acaba por “[...] priorizar o comum, o uniforme, o homogêneo, considerados como elementos constitutivos do universal. Nesta ótica, as diferenças são ignoradas ou consideradas um 'problema' a resolver" (Candau, 2011, p. 241 , grifo do autor). A vigilância constante, os discursos e os registros, assim como outras dinâmicas vivenciadas na instituição investigada revelam a tentativa usada na produção do padrão, do homogêneo.

Dessa forma, as representações de feminino e masculino que a escola reproduz, assim como também as regras de comportamento para meninas e meninos; as separações, expectativas lançadas para cada sexo, castigos para aquelas e aqueles que não seguem as normas, e as premiações para os que seguem; naturalização de comportamentos e desejos, falar ou não sobre sexo e sexualidade; entre outras questões percebidas no espaço escolar, são reproduzidas cotidianamente, no intuito de disciplinar os indivíduos, garantindo a construção de meninas e meninos, mulheres e homens condizentes com as noções de masculinidades e feminilidades que se tem e se defende. E essas noções produzidas e 
reproduzidas no espaço educacional estão relacionadas às noções existentes no meio social.

\section{CONSIDERAÇÕES FINAIS}

Ao eleger como campo investigativo uma escola pública municipal, entende-se que esse espaço educativo atua diretamente na produção e reprodução das feminilidades e masculinidades. Considerando um cenário social produtor e reprodutor de valores e hábitos que justificam e disseminam as desigualdades de gênero, torna-se premente o tencionamento dessas questões no espaço da escola.

Percebe-se que a escola atua ativamente no processo de construção das identidades de gênero dos indivíduos na medida em que delimita espaços e fronteiras, separa meninas dos meninos, lança expectativas diferenciadas, naturaliza noções de feminilidades e masculinidades, reproduz preconceitos, desconsideram as desigualdades, entre outras situações. Porém, é interessante destacar que a influência da escola não é simplesmente recebida pelas alunas e alunos. Essas e esses também estão diretamente envolvidos no processo de produção e reprodução do gênero. Algumas vezes, cumprem as determinações, outras vezes, reagem, negam, negociam, transgridem, e, assim, vão construindo suas identidades.

Observou-se também que as representações de feminilidades e masculinidades estão presentes em todo o espaço da escola, visíveis principalmente nos discursos e expectativas lançadas pelos profissionais da escola, delimitando lugares, atitudes, sentimentos, pertencimentos. Essas representações ora reproduzem noções e valores estereotipados e preconceituosos, ora desconstroem exatamente essas noções e valores, mostrando a diversidade de atitudes e percepções dentro de um mesmo espaço institucional.

As transgressões às normas institucionais são alvo de séria atenção por parte dos profissionais que nela atuam. A vigilância e a constante ameaça de punição são utilizadas como recursos valiosos no cumprimento da norma e na garantia do controle. O livro de ocorrências, no qual os casos de indisciplinas são registrados, expressa um meio encontrado para a institucionalização desse controle. Constata-se que, apesar dos discursos sobre o respeito ao diferente, as fronteiras da feminilidade e da masculinidade é constantemente vigiada, seja por uma ação direta das professoras e professores, seja a partir da consciência desse olhar, mesmo quando ele não se faz fisicamente presente.

Assim, compreende-se que as concepções de feminilidades e masculinidades são percebidas e elaboradas num contexto de múltiplos olhares e percepções. Percebe-se também ações paradoxais envolvendo preconceitos e, em seguida, tentativa de desconstrução. Em meio a essas diversas percepções e práticas, é que as noções de gênero vão sendo impostas, negociadas, transgredidas.

Ressalta-se a necessidade de haver momentos de discussões e reflexões sobre as relações e estereótipos de gênero no cotidiano da escola e, da mesma forma, proporcionar experiências formativas sobre gênero para professoras, professores e demais funcionários, assegurando um trabalho fundamentado e crítico na busca de uma escola mais inclusiva, não sexista e democrática. 


\section{REFERÊNCIAS}

ARROYO, M. G. currículo, território em disputa. Petrópolis, RJ: Vozes, 2011.

BRASIL, Base Nacional Comum Curricular. Ministério da Educação. Brasília, 2017.

BRASIL. Ministério da Educação e do Desporto. Secretaria de Educação Fundamental.

Referencial Curricular Nacional para Educação Infantil. Brasília, 1998.

BRASIL, Ministério da Educação e do Desporto, Secretaria de Educação Fundamental. Parâmetros curriculares nacionais. Brasília: MEC/SEF, 1997.

BRASIL, Lei de Diretrizes e Bases da Educação Nacional. Lei no 9.394/96, de 20 de dezembro de 1996.

BRASIL. Constituição Federal de 1988. Promulgada em 5 de outubro de 1988.

BENTO, B. A reinvenção do corpo: sexualidade e gênero na experiência transexual / Berenice Bento. - Rio de Janeiro: Garamond, 2006.

BUTLER, J. Problemas de gênero: feminismo e subversão da identidade / Judith Butler; Tadução, Renato Aguiar. - Rio de Janeiro, Civilização Brasileira: 2010.

CANDAU, V. M. F. Diferenças culturais, cotidiano escolar e práticas pedagógicas. Currículo sem Fronteiras, v.11, n.2, pp.240-255, Jul/Dez. 2011.

FINCO, D. Relações de gênero nas brincadeiras de meninos e meninas na educação infantil. Pro-Posições, v. 14, n. 3 (42) - set./dez. 2003.

FOUCALT, M. Vigiar e punir: nascimento de uma prisão; Tradução de Raquel Ramalhete. Petrópolis, Vozes, 1987.

LAPLATINE, F, 1943 - A descrição etnográfica / François Laplantine; [tradução João Manuel Ribeiro Coelho e Sérgio Coelho]. São Paulo: Terceira Margem, 2004.

LOBO, T. Currículo \& identidade na educação. Fortaleza: Livro Técnico, 2005.

LOURO, G. L. Gênero, sexualidade e educação: uma perspective pós-estruturalista. - 11. ed. Petrópolis, RJ: Vozes, 2010.

MCLAREN, P. Rituais na escola: em direção a uma economia política de símbolos e gestos na educação. Tradução Juracy C. Marques, Angela M. B. Biaggio; apresentação à edição brasileira Tomaz Tadeu da Silva; prefácio Henry Giroux. Petrópolis, RJ: Vozes, 1991.

MEYER, D. E. Gênero, sexualidade e Currículo. In: Educação para igualdade de gênero. Salto para o futuro, Ano XVIII, Boletim 26 - Novembro de 2008.

PAECHTER, C. Meninos e meninas: aprendendo sobre masculinidades e feminilidades. tradução, Rita Terezinha Schmidt. Porto Alegre: Artmed, 2009.

SCOTT, J. Gênero: uma categoria útil para análise histórica. Educação e Realidade, Porto Alegre, V. 16, n. 2, 1990.

TOSCANO, M. Estereótipos sexuais na educação: um manual para o educador. Petrópoles, RJ: Vozes, 2000.

WOODWARD, K. Identidade e diferença: introdução teórica e conceitual. In: SILVA,T. T. Et all (org) Identidade e diferença: a perspectiva dos estudos culturais. Petrópolis, RJ: Vozes, 2012.

Recebido em: 05/11/2021

Aprovado em: 05/12/2021

Publicado em: 10/12/2021 